Gut, 1975, 16, 118-124

\title{
Mechanisms of lipid loss from the small intestinal mucosa
}

\author{
RICHARD WALDRAM 1 \\ From the Gastrointestinal Laboratory, St Thomas' Hospital, London
}

SUMMARY Many water-soluble compounds have been shown to pass from the small intestinal mucosa into the lumen. In this work, the loss of lipids from the mucosa was investigated by perfusion experiments in rats, using $0.15 \mathrm{M} \mathrm{NaCl}$ or buffer solutions over a range of $\mathrm{pH}$, with or without the addition of 5.7 or $11.4 \mathrm{mM}$ taurocholic acid. Perfusates were extracted for the estimation of individual lipids and for DNA, which is a measure of cell loss.

The results suggest that free fatty acids reach the lumen by diffusion and that their solubility in the luminal fluid is a factor determining their rate of loss. Triglycerides, cholesterol, phosphatidyl ethanolamine, and phosphatidyl choline are present only as the result of desquamation of mucosal cells.

The accumulation of lipid in the lumen of intestinal loops (Blitstein and Erenthal, 1891; Angevine, 1929) shows that endogenous lipid passes from the mucosa into the lumen. In man the faeces contain 0.7-1.0 g lipid/day during fasting (Bouchier, Kellock, and Manousos, 1963; Blomstrand, 1963), but this is no indication of the amount of endogenous lipid. In the fasting dog, faecal lipids rise approximately threefold when bile is diverted (Sperry, 1927; Pessoa, Kim, and Ivy, 1953) indicating that bile is not the most important source of endogenous lipid, and that a high proportion is normally reabsorbed.

Other authors have claimed that neutral lipids (Burr, MacPherson, and Tidwell, 1960; Lough, Felinski, and Garton, 1963; Brenner, Vazza, and De Tomás. 1963) and sterols (Wilson and Reinke, 1968; Simmonds, Hofmann, and Theodor, 1967) pass from the mucosa into the lumen, but Cotton (1972) made the first systematic study. Using a perfusion technique in rats, he measured deoxyribonucleic acid, a measure of cell loss (Davidson, Leslie, and White, 1951), and lipids in saline perfusates of the small bowel, and concluded that triglycerides, cholesterol, phosphatidyl ethanolamine, and phosphatidyl choline in perfusates were wholly derived from desquamated cells, but fatty acids 'exuded' from the mucosa. Fatty acid loss was related to the rate of perfusion,

'Present address: The Liver Unit, King's College Hospital, Denmark Hill, London, SE5

Received for publication 4 December 1974. but loss of the other lipids was not. Gas-liquid chromatography showed that the principal fatty acids were palmitic, oleic, stearic, and linoleic.

In these experiments the perfusion fluid was normal saline in which lipids are almost insoluble. The small bowel lumen in the normal animal contains bile salt micelles in which fatty acids, phospholipids, and, to a lesser extent, cholesterol dissolve. In addition, the solubility of long-chain fatty acids depends on the $\mathrm{pH}$, which increases from 5 to 6 in the duodenum to 7 to 8 in the ileum. Loss of lipids by mechanisms other than desquamation may have been limited in Cotton's experiments by the use of saline, and the present experiments were done to show whether loss of lipids is related to their solubility in the perfusing fluid.

\section{Methods}

\section{ANIMAL EXPERIMENTS}

Sixteen adult male Wistar rats, fed on Spiller's autoclave diet, and weighing 250-280 g were used. Half the animals were fasted of food for $24 \mathrm{hr}$ before the experiment and they were kept in false bottomed cages to prevent coprophagy. Water was allowed ad libitum. The remainder were taken from the animal house approximately $90 \mathrm{~min}$ before the first perfusion. Anaesthesia was induced with ether and maintained with intraperitoneal pentobarbitone. A tracheostomy was performed, the abdomen opened and polyethylene cannulae were inserted into the small 
bowel immediately distal to the ligament of Treitz and proximal to the caecum, isolating the whole small bowel from bile and pancreatic juice. Intestinal contents were washed out with $0.15 \mathrm{~mol} \mathrm{NaCl} / 1$ for $20 \mathrm{~min}$ before the first perfusion. Perfusion fluids were $0.15 \mathrm{~mol} \mathrm{NaCl} / 1$, phosphate or glycine buffer solutions at $\mathrm{pH} 3 \cdot 7,5 \cdot 4,7 \cdot 4$, and $9 \cdot 7$, with or without the addition of 5.7 or $11.4 \mathrm{mM}$ taurocholic acid (TC), stated by the makers (Calbiochem) to be $98 \%$, with $2 \%$ of unconjugated bile acids. The mean $\mathrm{pH}$ of saline used was 5.5 and of the taurocholic acid solutions was 5.9 (Cambridge pH meter). Perfusion fluids were warmed to $39^{\circ} \mathrm{C}$ before use. All perfusions were at a rate of $250 \mathrm{ml} / \mathrm{hr}$, which does not damage the mucosa (Loehry, 1970). Up to six 20-min perfusates from each animal were collected into vessels containing $4 \mathrm{ml} 0.2 \mathrm{M}$ EDTA in order to inactivate any ribonuclease. During perfusion, the bowel was gently unkinked to allow clumps of cells to pass into the collecting vessel. Perfusates were homogenized at low speed to break up cell clumps; $40 \mathrm{ml}$ was taken for estimation of deoxyribonucleic acid (DNA) and $40 \mathrm{ml}$ for lipid analysis.

Suspensions of mucosal cells were obtained from four rats by opening the small bowel after washing with saline and scraping the mucosal surface from end to end with a glass slide. The mass of cells was shaken in $40 \mathrm{ml} 0.15 \mathrm{M} \mathrm{NaCl}$, and centrifuged at $4500 \mathrm{~g}$ for 20 minutes. The pellet was resuspended, washed four times with $0 \cdot 15 \mathrm{M} \mathrm{NaCl}$, and finally resuspended in $80 \mathrm{ml} 0 \cdot 15 \mathrm{M} \mathrm{NaCl}$.

\section{CHEMICAL METHODS}

Estimation of DNA was performed by the method of Croft and Lubran (1965). The mean recovery of standard DNA added to perfusates was $74 \%$ both in saline and in $11.4 \mathrm{mM}$ TC and recovery did not vary with concentration in the range $0 \cdot 5-20$ ng-atoms DNA-P $/ \mathrm{ml}$. A correction factor of 1.35 was therefore applied. The coefficient of variation of five estimations was $3.7 \%$ at a concentration of $9.2 \mathrm{ng}$ atoms DNA-P/ml and $7.8 \%$ at $1.8 \mathrm{ng}$-atoms DNA-P/ $\mathrm{ml}$.

Lipids were extracted from perfusates by the method of Cotton (1972) using chloroform and methanol, but employing smaller volumes and omitting the second extraction. The organic layer was evaporated to dryness and the lipids were redissolved in a small volume of chloroform. Impurities derived from the TC solution were removed from the final extract by washing with an equal volume of buffer at $\mathrm{pH} 5.4$. Recoveries of standard lipids added to perfusates were: triglyceride (tripalmitin/tirolein 2:1 w/w) $97 \%$, free fatty acid (palmitic/oleic 2:1 w/w) $90 \%$, cholesterol
$91 \%$, phosphatidyl choline $88 \%$, phosphatidyl ethanolamine $94 \%$, and sphingomyelin $84 \%$. Coefficients of variation in six recovery experiments were 5 to $11 \%$. Recoveries from perfusates containing TC were slightly lower.

Lipids were then separated by thin-layer chromatography on Silica gel-G (Merk) and lipid spots measured by direct densitometry (Cotton, 1971). Individual triglycerides and fatty acids were not separated. Standard lipids (Koch Light Laboratories; Sigma) were developed with perfusate samples on the same plate, When the constituents of a neutral lipid mixture were measured on four different plates the mean coefficient of variation was $4 \cdot 2 \%$.

STATISTICAL ANALYSES

The significance of differences between means were calculated by Student's $t$ test. Regression lines were calculated by the method of least squares.

MEASUREMENT OF SOLUBILITY OF FATTY

ACIDS IN PERFUSION SOLUTIONS

Solubility of fatty acids in the perfusion solution was thought likely to be a factor determining their rate of loss from the mucosa, and was therefore measured in each of the perfusion solutions in vitro. The major long-chain fatty acids present in saline perfusates are palmitic, stearic, oleic, and linoleic (Cotton, 1971). Unfortunately it was not possible to measure the solubility of these acids in the proportions in which they occur in perfusates, because the mixture was found to be solid at body temperature and all methods of measuring micellar solubility require equilibrium between a micellar and an oil phase. The solubility of oleic acid was therefore measured, since it is liquid at $39^{\circ} \mathrm{C}$, although the effects of changes in pH and TC concentration on solubility may be less marked for the saturated acids (Hofmann and Mekhjian, 1973). Solubility was measured by the method of turbidimetry which depends upon scattering of light by the emulsion which forms when micellar solubility is exceeded (Borgström, 1967). Amounts of oleic acid in chloroform $(10 \mu \mathrm{g}-10 \mathrm{mg})$ were placed in a series of test tubes and the chloroform was evaporated under a stream of nitrogen. Of the perfusion solution to be tested, $5.0 \mathrm{ml}$ was added to each tube and the contents were agitated for two minutes. The tubes were brought to $39^{\circ} \mathrm{C}$ on a water bath and agitated again for two min before measuring their absorbence on a Zeitz PMQ3 spectrophotometer, using the test solution as the blank. The endpoint was independent of the wavelength used. Solubility was measured in each of the perfusion solutions, the highest concentration of oleic acid to form a clear solution with no oil phase 
present being taken as the limit of micellar solubility.

\section{Results}

\section{HISTOLOGY}

No damage was seen in sections of jejunum or ileum after perfusion for two hours with saline or $11.4 \mathrm{mM}$ TC (fig 1).

\section{SALINE AND TC PERFUSIONS}

Fifty-five perfusions were performed in nine animals.

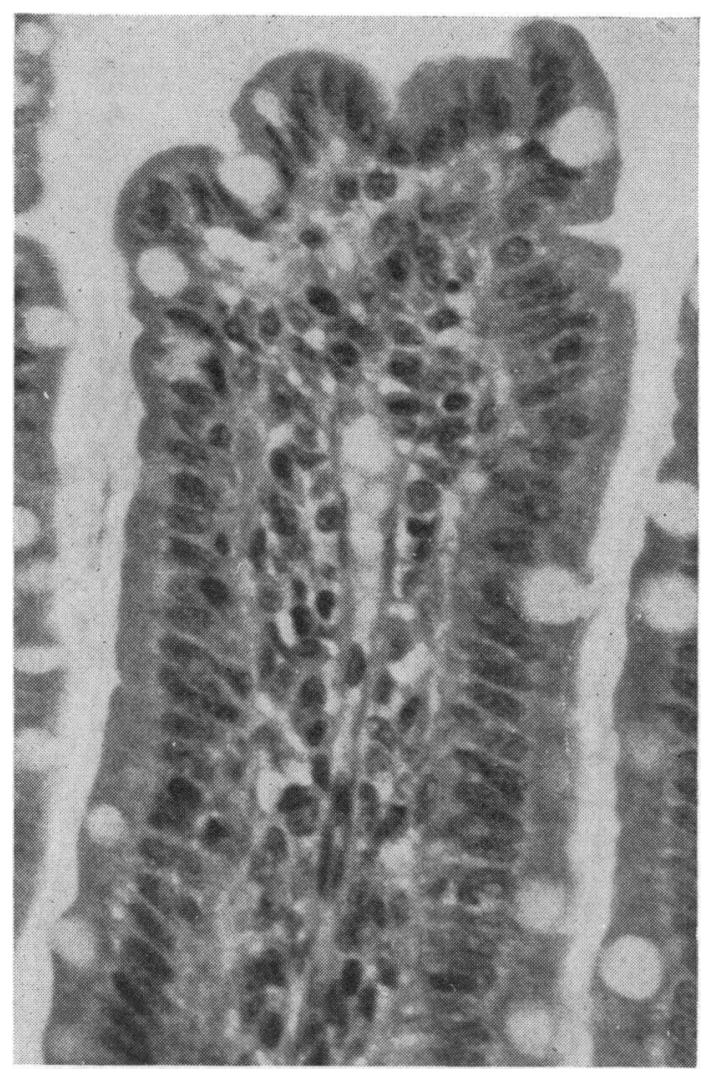

Fig 1 Rat jejunum following perfusion with $11.4 \mathrm{mM} T \mathrm{TC}$ for two hr ((haematoxylin and eosin, $\times 150)$.
There was no significant change in the amounts of DNA or lipids with time, with the exception that in each animal there was significantly more phosphatidyl choline $(\mathrm{P}=<0.01)$ in the first $11.4 \mathrm{mM}$ TC perfusion (mean $372 \mu \mathrm{g} \pm \mathrm{SD} 88 \mu \mathrm{g}, \mathrm{n}=3$ ) than in the second $(166 \mu \mathrm{g} \pm 20 \mu \mathrm{g})$ or subsequent perfusates. Nor was there any significant difference in amounts of lipids or DNA in perfusates from fasted animals and those not fasted.

Amounts of DNA and each lipid measured are shown in table I. Since individual triglycerides and free fatty acids were not separated on the chromatograms, the term 'triglyceride' refers to total triglycerides and 'fatty acid' to total free fatty acids. There was no significant difference between saline and $5.7 \mathrm{mM}$ TC perfusates in the amounts of DNA or any lipid present, but in each case there was a

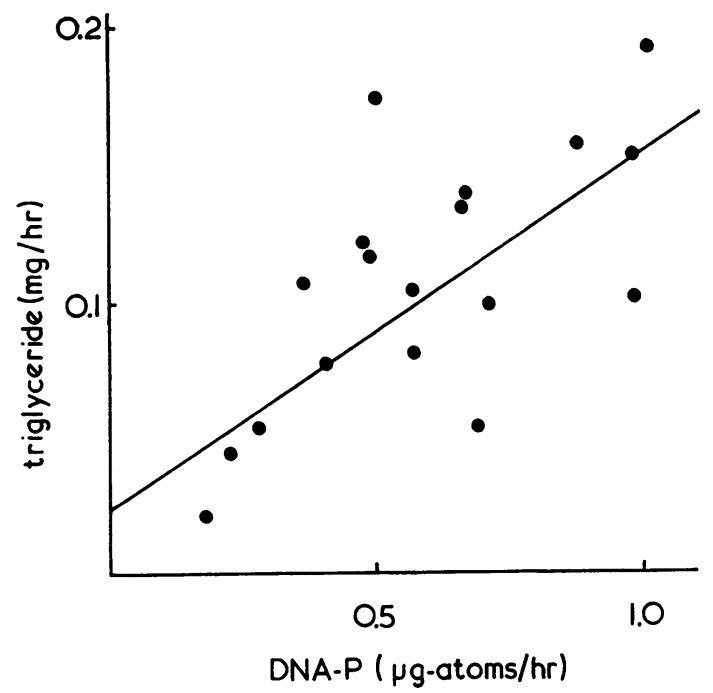

Fig 2 The correlation between triglyceride and DNA in $0.15 \mathrm{M} \mathrm{NaCl}$ perfusates. Similar correlations were found between DNA and cholesterol, phosphatidyl ethanolamine, and phosphatidyl choline (see table II). $\mathrm{r}=0.65 ; \mathrm{p}=<0.01$.

\begin{tabular}{|c|c|c|c|c|c|}
\hline & \multicolumn{5}{|c|}{ Perfusion Solution } \\
\hline & $01 \cdot 5 \mathrm{M} \mathrm{NaCl}$ & $\mathbf{P}$ & $0.15 \mathrm{M} \mathrm{NaCl}+5.7 \mathrm{mMTC}$ & $\mathbf{P}$ & $0.15 \mathrm{M} \mathrm{NaCl}+11.4 \mathrm{mMTC}$ \\
\hline $\begin{array}{l}\text { Triglyceride }(\mu \mathrm{g} / \mathrm{hr}) \\
\text { Fatty acids }(\mu \mathrm{g} / \mathrm{hr}) \\
\text { Cholesterol }(\mu \mathrm{g} / \mathrm{hr}) \\
\text { Phosphatidyl ethanolamine }(\mu \mathrm{g} / \mathrm{hr}) \\
\text { Phosphatidyl choline }(\mu \mathrm{g} / \mathrm{hr}) \\
\text { DNA-P (ng-atoms } / \mathrm{hr})\end{array}$ & $\begin{array}{l}103 \pm 44 \\
227 \pm 105 \\
135 \pm 49 \\
278 \pm 137 \\
295 \pm 143 \\
600 \pm 258\end{array}$ & $\begin{array}{l}\text { NS } \\
\text { NS } \\
\text { NS } \\
\text { NS } \\
\text { NS } \\
\text { NS }\end{array}$ & $\begin{array}{l}109 \pm 40 \\
258 \pm 101 \\
124 \pm 55 \\
236 \pm 142 \\
224 \pm 148 \\
529 \pm 229\end{array}$ & $\begin{array}{l}<0.05 \\
<0.001 \\
<0.001 \\
<0.001 \\
<0.001 \\
<0.01\end{array}$ & $\begin{array}{l}195 \pm 114 \\
711 \pm 306 \\
344 \pm 119 \\
606 \pm 196 \\
564 \pm 231 \\
934 \pm 330\end{array}$ \\
\hline
\end{tabular}

Table I Perfusate lipids and DNA-P in three perfusion solutions (mean $\pm 1 S D$ ) 


\begin{tabular}{|c|c|c|c|}
\hline & \multicolumn{3}{|l|}{ Perfusion Solution } \\
\hline & $0 \cdot 15 \mathrm{M} \mathrm{NaCl}$ & $5.7 m M T C+0.15 M \mathrm{NaCl}$ & $11.4 \mathrm{mMTC}+0.15 \mathrm{M} \mathrm{NaCl}$ \\
\hline DNA/triglyceride & $\begin{array}{l}n=18 \\
r=+0.65 \\
P=<0.01\end{array}$ & $\begin{array}{l}n=16 \\
r=+0.74 \\
P=<0.003\end{array}$ & $\begin{array}{l}n=21 \\
r=+0.68 \\
P=<0.004\end{array}$ \\
\hline DNA/fatty acids & $\begin{array}{l}n=18 \\
r=+0.2 \\
0.3<p<0.4(N S)\end{array}$ & $\begin{array}{l}n=16 \\
r=-0.3 \\
0.2<P<0.3(N S)\end{array}$ & $\begin{array}{l}n=21 \\
r=+0.2 \\
0 \cdot 3<P<0.4 \text { (NS) }\end{array}$ \\
\hline DNA/cholesterol & $\begin{array}{l}n=18 \\
r=+0.65 \\
P=<0.005\end{array}$ & $\begin{array}{l}n=16 \\
r=+0.47 \\
P=<0.05\end{array}$ & $\begin{array}{l}n=21 \\
r=+0.63 \\
P=<0.003\end{array}$ \\
\hline DNA/phosphatidyl ethanolamine & $\begin{array}{l}n=16 \\
r=+0.84 \\
P=<0.001\end{array}$ & $\begin{array}{l}n=11 \\
r=+0.81 \\
P<0.001\end{array}$ & $\begin{array}{l}n=16 \\
r=+0.59 \\
P=<0.02\end{array}$ \\
\hline DNA/phosphatidyl choline & $\begin{array}{l}n=16 \\
r=+0.81 \\
P=<0.001\end{array}$ & $\begin{array}{l}\mathbf{n}=11 \\
\mathbf{r}=+0.87 \\
\mathbf{P}=<0.001\end{array}$ & $\begin{array}{l}n=13^{2} \\
r=+0.85 \\
P=<0.001\end{array}$ \\
\hline
\end{tabular}

Table II Correlations between DNA and lipids in perfusate samples ${ }^{1}$

${ }^{1} \mathrm{n}=$ number of observations, $\mathrm{r}=$ correlation coefficient $(x / y)$

${ }^{2}$ With first perfusate from each animal excluded

significant rise in $11.4 \mathrm{mM}$ perfusates. Significant positive correlations were found between DNA and triglycerides, cholesterol, phosphatidyl ethanolamine, and phosphatidyl choline in all three perfusion solutions (fig 2 and table II). Amounts of fatty acids were not related to DNA in any perfusion solution.

Cholesterol esters, monoglycerides, diglycerides, sphingomyelin, and lysolecithin were not present in measurable quantities.

\section{PERFUSION OF BUFFER SOLUTIONS}

Six or eight perfusions were performed with buffer at each $\mathrm{pH}$ value. Neither DNA, triglyceride, nor cholesterol were related to $\mathrm{pH}$ and, as before, there was a significant correlation between DNA and triglyceride $(\mathrm{r}=+0.76, \mathrm{p}=<0.001, \mathrm{n}=24)$ and between DNA and cholesterol $(r=+0.56, P=$ $<0.02, n=24)$. Amounts of fatty acids were not related to DNA and increased significantly with each rise in $\mathrm{pH}$ above $\mathrm{pH} 5.4$ (fig 3). Phospholipids were not measured in these experiments.

PERFUSION OF TC IN BUFFER AT PH $9 \cdot \mathbf{7}$

Amounts of fatty acids were again not proportional to DNA and increased significantly with each concentration of TC (fig 3).

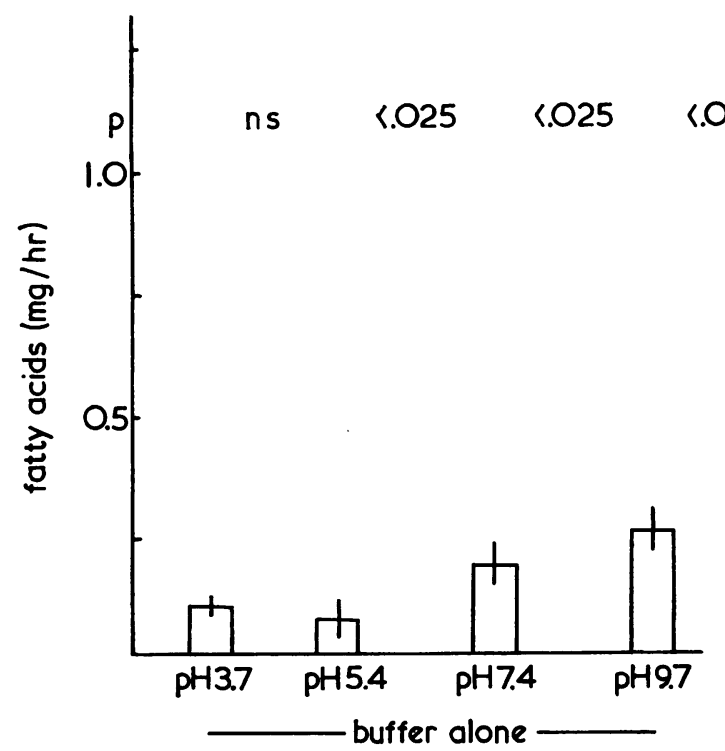

Fig 3 Fatty acids in perfusates; the effect of $\mathrm{pH}$ and TC in the perfusion solution (mean \pm 1 $S D)$.

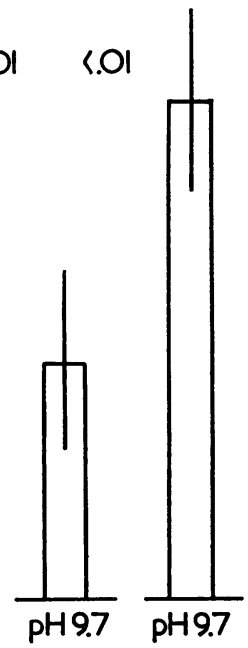


MUCOSAL CELL SUSPENSIONS

Amounts of each lipid and of DNA were measured in suspensions of mucosal cells from four animals. The lipid compositions of mucosal cell suspensions and saline perfusates were found to be similar, except for fatty acids. They are compared in fig 4, where results are expressed as $\mu \mathrm{g}$ lipid/ng-atom DNA-P. For each lipid there was no significant difference between the ratio in cell suspensions and in perfusates, except that there was approximately 18 times more fatty acid in the perfusates than in cell suspensions $(P=<0.001)$.

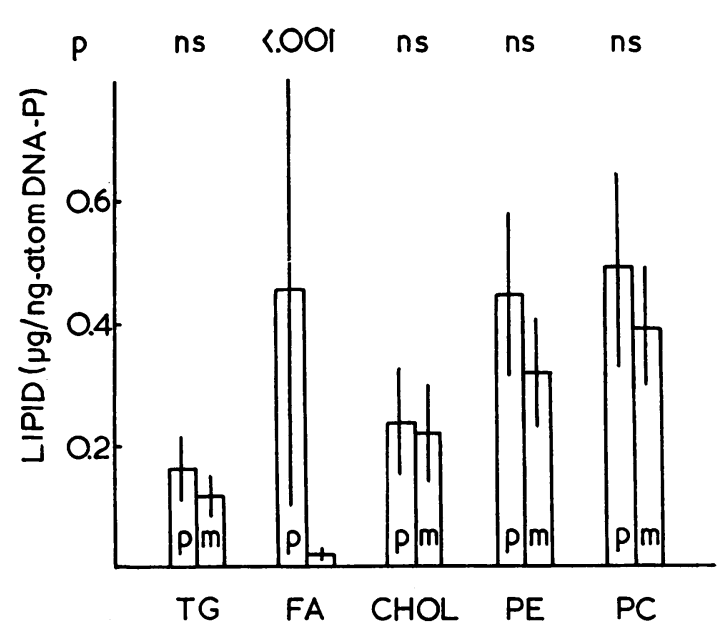

Fig 4 Individual lipids in saline perfusates and mucosal cell suspensions ( $p=$ perfusate, $m=$ mucosal cell suspension, mean $\pm 1 S D)$.

\section{SOLUBILITY OF OLEIC ACID IN PERFUSION SOLUTIONS in vitro}

Stable emulsions did not form in solutions at $\mathrm{pH} 3 \cdot 7$ and 5.4 except in those containing $11.4 \mathrm{mM}$ TC. The endpoint was then taken to be the appearance of oil droplets above a clear solution. Figure 5 shows the relationship between the rate of loss of fatty acids from the mucosa in perfusion experiments and the solubility of oleic acid in vitro in five of the solutions used. In the three remaining solutions the solubility was less than $10 \mu \mathrm{g} / \mathrm{ml}$ and could not be measured accurately by this method.

\section{Discussion}

The rate of loss of DNA from the mucosa during perfusions with saline approximates to the normal turnover rate for the rat (Cotton, 1972), and the rates of loss of DNA and lipids remained constant with time. The increased rate of loss of DNA in

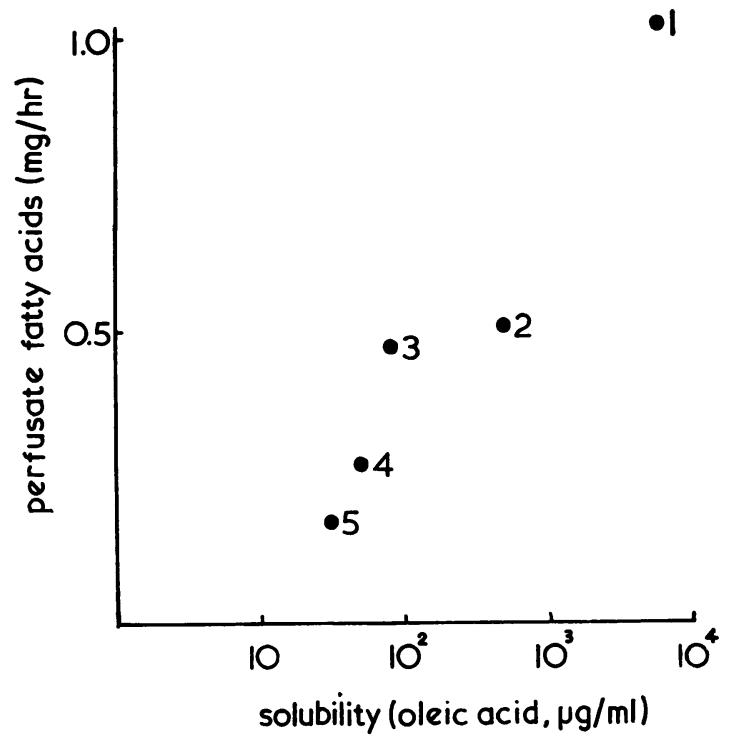

Fig 5 Relationship between total fatty acids in perfusates and the solubility of oleic acid in perfusion solutions in vitro $(1=11.4 \mathrm{mMTC}, \mathrm{pH} 9.7 ; 2=5.7 \mathrm{mM}$ TC, $p H 9 \cdot 7 ; 3=11 \cdot 4 m M T C, p H 5 \cdot 7 ; 4=$ buffer, $p H$ 9.7; $5=$ buffer, $p H 7 \cdot 4$ ).

$11.4 \mathrm{mM}$ TC perfusates may have been due to the $2 \%$ of unconjugated acids present as impurities in the solution, although their concentration was insufficient to cause histologically detectable damage (Harries and Sladen, 1972). Fasting did not alter the rate of lipid loss, but lipid was only $2.5 \%$ of the dry weight of the diet and about 90 min elapsed between removal of food from animals not fasted and the first perfusion.

There are several routes by which lipids may pass from the mucosa into the lumen:

1 By the desquamation of cells: the correlations between lipids and DNA in perfusates and the similarity between the lipid composition of perfusates and mucosal cell suspensions suggest that desquamation is the only important mechanism for the loss of triglycerides, cholesterol and phospholipids.

2 By passage through extrusion zones at the tips of the villi: this implies that there are a few, relatively large holes in the mucosa and is not consistent with the finding that the blood to lumen clearance of fructose is much greater than glucose although the molecules are the same size (Axon, 1973). Large molecules, such as horseradish peroxidase, do not reach the lumen by this route (Hugon and Borgers, 1968) and the appearance in perfusates of $1^{14} \mathrm{C}$ palmitic acid bound to albumin injected into the 
bloodstream is negligible. (Waldram, unpublished observations, 1971).

3 By passage between cells: this seems unlikely on anatomical grounds, since the lateral membranes of adjacent cells are fused together near their apices. Although horseradish peroxidase (Hugon and Borgers, 1968) and colloidal iron (Loehry, Parish, and Baker, 1973) can be demonstrated in the intercellular space after parenteral injection, neither substance can be shown to cross the tight junction. However, it is theoretically possible that lipids might enter the lateral membrane from the intercellular space, diffuse along it and leave from the apical membrane without entering the cell, a route proposed for sodium transport in the colon (Edmonds and Pilcher, 1972).

4 By passage across the plasma membrane: this is the most likely route for water-soluble compounds over a wide range of molecular weights (Loehry, Axon, Hilton, Hider, and Creamer, 1970).

The rate of passage of a solute across a membrane separating two stirred compartments depends upon the characteristics of the membrane and on the concentration difference, provided that the fluids on each side are the same and the solutions are dilute. However, the apical plasma membrane separates two fluids that are not the same and additional factors may become important: the solubility of a substance may then be greater on one side than the other and $\mathrm{pH}$ differences may alter the partition of weak acids and bases (Shore, Brodie, and Hogben, 1957). If a substance within the cell is insoluble in the luminal fluid, there will be no movement across the membrane despite the concentration difference, and, when solubility is low, net movement diminishes as saturation is approached.

The physical state of lipids within the cell is not known. Lipid droplets are scanty in the apical regions of the cell, but lipoproteins have been described which may bind fatty acids (Ockner, Pittman, and Yager, 1972) and cholesterol (Glover and Green, 1956). Absorbed lipids may also be incorporated in the structure of the membrane (Dermer, 1966).

The solubility of long-chain fatty acids in water is low, but is increased by a rise in $\mathrm{pH}$ above the $\mathrm{pK}_{\mathrm{a}}$ (approximately 6-7) and by the presence of bile acid micelles. The critical micellar concentration of taurocholic acid alone $(7.0 \mathrm{mM})$ is reduced by the addition of long-chain fatty acids (Hofmann, 1961). Although the method used for measuring fatty acid solubility is not capable of great accuracy, it was sufficient for the purpose of the present experiments, and it was shown that the amounts of fatty acids in perfusates appeared to be related exponentially to the solubility of oleic acid in each perfusion solution, supporting the hypothesis that the rate of loss of fatty acids from the mucosa is related to their solubility in the luminal fluid. The behaviour of triglycerides and cholesterol can also be related to their physical properties: triglycerides are non-polar and do not ionize; their solubility in water is therefore negligible and is not increased in micellar solutions of bile acids or by changes in $\mathrm{pH}$. The solubility of cholesterol in water is also negligible, and is only dissolved by bile acid micelles if they are expanded by a polar lipid (Neiderhiser and Roth, 1968). Loss of these compounds occurred by desquamation only. Phospholipids, on the other hand, are polar lipids and have considerable solubility in bile acid micelles, but apart from an excess of phosphatidyl choline in the initial $11.4 \mathrm{mM}$ TC perfusate from each animal, loss was also the result of desquamation alone. This suggests that only a small quantity of phosphatidyl choline is available to cross the membrane and that the remainder is fixed within structural components of the cell.

Fatty acids leaving the cell must cross the lipid membrane and the unstirred water layer before reaching the bulk of the luminal fluid. Wilson, Sallee, and Dietschy (1971) have presented evidence that the rate-limiting step in the absorption of long-chain fatty acids is diffusion across the unstirred layer. Results of the present experiments suggest that passage across the unstirred layer may also be rate-limiting for fatty acid loss, a hypothesis supported by Cotton's observation (1972) that the rate of fatty acid loss was directly related to the perfusion rate, the thickness of the layer being reduced by rapid movement of the bulk of the luminal fluid (Wilson et al, 1971).

Endogenous lipid within exfoliated cells could amount to $20 \mathrm{~g}$ /day in normal man (Cotton, 1972) but the quantitative significance of fatty acid loss from the mucosa is difficult to assess. Results of the present experiments suggest that fatty acid loss would be reduced in the absence of bile. During triglyceride absorption, the polar products of lipolysis-fatty acids and monoglycerides-are reconstituted to triglyceride within the cell, so that intracellular concentrations of fatty acids remain low and absorption continues. Triglyceride cannot escape into the lumen and is incorporated into chylomicrons. The return of fatty acids to the lumen represents a defect in the absorptive mechanism, but in the normal animal most of the endogenous lipid in the lumen will be reabsorbed. However, in coeliac disease the activities of mucosal enzymes are reduced, including fatty acyl CoA ligase (Dawson and Isselbacher, 1960). Gallagher, Playoust, and 
Symons (1971) used rats infected with Nippostrongylus braziliensis as a model of coeliac disease and the animals showed subtotal villous atrophy and reduction in mucosal enzymes. Although uptake of ${ }^{14} \mathrm{C}$-oleic acid and its incorporation into triglycerides was less in infected animals than in controls, the concentration of ${ }^{14} \mathrm{C}$-oleic acid within the mucosal cells was greater. Absorption of octanoic acid, which is absorbed without esterification into the portal vein, was normal. This suggests that the defect in long-chain fatty acid absorption was only in the ability of mucosal enzymes to esterify the fatty acids that had entered the cell and to prevent their return to the lumen.

The steatorrhoea of coeliac disease may thus have three components: (1) failure to absorb exogenous and endogenous lipids due to loss of surface area, (2) an increased loss of lipid within exfoliated mucosal cells due to the increased turnover rate (Croft, Loehry, and Creamer, 1968), and (3) return of absorbed fatty acids to the lumen due to failure of esterification.

It is a pleasure to thank $\operatorname{Dr} B$. Creamer for encouragement and advice and Mrs J. Caddy for technical assistance. The work was supported by the Endowment Fund of St Thomas' Hospital.

\section{References}

Angevine, R. W. (1929). Fat excretion VI. Excretion by Thiry Vella fistulas. J. biol. Chem., 82, 559-565.

Axon, A. T. R. (1973). MD Thesis, Cambridge University.

Blitstein, M., and Erenthal, W. (1891). Neue Versuche zur Physiologie des Darmkanals. Pfügers Arch. ges. Physiol., 48, 74-99.

Blomstrand, R. (1955). A study on the intestinal absorption of fat in normal adults and in non-tropical sprue with carbon-labelled oleic acid and palmitic acid. Acta med. scand., 152, 129-138.

Borgström, B. (1967). Partition of lipids between emulsified oil and micellar phases of glyceride and bile salt dispersions. J. Lipid Res., 8, 598-608.

Bouchier, I. A. D., Kellock, T. D., and Manousos, O. (1963). The origin of faecal fat in subjects without steatorrhoea. In Proceedings of the 2nd World Congress of Gastroenterology, Munich, Vol. 2, pp. 659-661.

Brenner, R. R., Vazza, D. V., and De Tomás, M. E, (1963). Effect of a fat-free diet and of different dietary fatty acids (palmitate, oleate, and linoleate) on the fatty acid composition of fresh water fish lipids. J. Lipid Res., 4, 341-355.

Burr, W. W, Jr., McPherson, J. C., and Tidwell, H. C. (1960). Secretion of labelled blood lipids into the intestine. J. Nutr., 70, 171175.

Cotton, P. B. (1971). The contribution of the mucosa to non-dietary lipid in the intestinal lumen. MD Thesis, Cambridge University.

Cotton, P. B. (1972). Non-dietary lipid in the intestinal lumen. Gut, $13,675-681$.

Croft, D. N. . Loehry, C. A., and Creamer,'B. (1968). Small bowel cell loss and weight loss in the coeliac syndrome. Lancet, 2 , 68-71.

Croft, D. N., and Lubran, M. (1965). The estimation of deoxyribonucleic acid in the presence of sialic acid: application to analysis of human gastric washings. Biochem. J., 95, 612-620.

Davidson, J. N., Leslie, I., and White, J. C. (1951). The nucleic acid content of the cell. Lancet, 1, 1287-1290.

Dawson, A. M., and Isselbacher, K. J. (1960). Studies on lipid metabolism in the small intestine with observations on the role of bile salts. J. clin. Invest., 39, 730-740.

Dermer, K. (1960). Ultrastructural changes in the plasma villous membrane during fat absorption. J. ultrastruct. Res., 20 51-72.

Edmonds, C. J., and Pilcher, D. (1972). Sodium transport mechanisms of the large intestine. In Transport Across the Intestine, edited by W. L. Burland and P. D. Samuel, pp. 43-57. Churchill Livingstone. Edinburgh and London.

Gallagher, N. D., Playoust, M. R., and Symons, L. E. A. (1971). Mechanisms of fat malabsorption in rats infected with Nippostrongylus braziliensis. Gut, 12, 1007-1010.

Glover, J., and Green, P. (1956). Studies on the absorption and metabolism of sterols: mode of absorption. In Biochemical Problems of Lipids, edited by G. Popjak and E. LeBreton. Butterworths, London.

Harries, J. T., and Sladen, G. E. (1972). The effects of different bile acids on the absorption of fluid, electrolytes and monosaccharides in the small intestine of the rat in vivo. Gut, 13, 596603.

Hofmann, A. F. (1961). Micellar solubilization of fatty acids and monoglycerides in bile salt solutions. Nature (Lond.) 190, 1106 1100 .

Hofmann, A. F., and Mekhjian, H. S. (1973). In The Bile Acids. edited by P. P. Nair and A. Kritchevsky, Vol. 2, p. 118. Plenum, New York and London.

Hugon, J. S., and Borgers, L. (1968). Absorption of horseradish peroxidase by the mucosal cells of the duodenum of the mouse, (1) The fasting animal. J. Histochem. Cytochem. $16 \quad 229-236$.

Loehry, C. A. (1970). M D.., Thesis, Cambridge University.

Loehry, C. A., Axon, A. T. R., Hilton, P. J., Hider, R. C., and Creamer, B. (1970). Permeability of the small intestine to substances of different molecular weight. Gut, 11, 466-482.

Loehry, C. A., Parish, D., and Baker, J. (1973). The permeability of the small intestine: a study using iron. Gut, 14, 773-778.

Lough, A. K.. Felinski, L., and Garten, G. A. (1963). Thoracic duct lymph lipids of the sheep. In Biochemical Problems of Lipids, edited by A. C. Frazer. Butterworths, London, Elsevier, Amsterdam.

Neiderhiser, D. H., and Roth, H. P. (1968). Cholesterol solubilization by solutions of bile salts and bile salts plus lecithin. Proc. Soc. exp. Biol. (N.Y.), 128, 221-225.

Ockner, R. K., Pittman, J. P., and Yager, J. L. (1972). Differences in the intestinal absorption of saturated and unsaturated fatty acids. Gastroenterology, 62, 981-992.

Pessoa, V. C., Kim, K. S., and Ivy, A. C. (1953). Fat absorption in absence of bile and pancreatic juice. Amer. J. Physiol., 174, 209-218.

Shore, P. A., Brodie, B. B., and Hogben, C. A. M. (1957). The gastric secretion of drugs: a $\mathrm{pH}$ partition hypothesis. $J$. Pharmacol. exp. Ther., 119, 361-369.

Simmonds, W. J., Hofmann, A. F., and Theodor, E. (1967). Absorption of cholesterol from a micellar solution: intestinal prefusion studies in man. J. clin. Invest., 46, 874-890.

Sperry, W. M. (1927). Lipid excretion. V. Study of the relationship of bile to fecal lipids with special reference to certain problems of sterol metabolism. J. biol. Chem., 71, 351-378.

Wilson, J. D., and Reinke, R. T. (1968). Transfer of locally synthesised cholesterol from intestinal wall to intestinal lymph. $J$. Lipid Res., 9, 85-92.

Wilson, F. A., Sallee, V. L., and Dietschy, J. M. (1971). Unstirred water layers in intestine: rate determinant of fatty acid absorption from micellar solutions. Science, 174, 1031-1033. 